\title{
Arterial vascularization of the brain of the agouti (Dasyprocta aguti Linnaeus, 1766)
}

\section{Vascularização arterial da base do encéfalo de cutias (Dasyprocta aguti Linnaeus, 1766)}

\author{
Roberto Sávio Bessa da Silva ${ }^{1}$; Gleidson Benevides de Oliveira²; Carlos Magno \\ Oliveira Junior ${ }^{2}$; Ferdinando Vinicius Fernandes Bezerra ${ }^{2}$; Felipe Venceslau \\ Câmara $^{2}$; Radan Elvis Matias de Oliveira ${ }^{3}$; Moacir Franco de Oliveira ${ }^{4}$
}

\begin{abstract}
The agouti, a rodent that is geographically distributed throughout South America, is greatly valued for its meat. This paper describes the arterial vascularization of the base of the agouti's brain, characterizing behavior, and arterial origin and distribution. Ten animals from the Center for the Multiplication of Wild Animals (CEMAS/UFERSA) were used and the study was approved by SISBIO (report number 324131) and the Ethics Committee on Animal Use (CEUA/UFERSA) (protocol 02/2010). After euthanasia, the animals were incised in the thoracic cavity by an injection of red-stained Neoprene latex 650 and the skulls were subsequently opened. The brains were extracted from the skulls for ventral surface analysis and then fixed in an aqueous $10 \%$ formaldehyde solution. The agouti's arterial vascularization of the brain has two main components, namely the carotid and vertebrobasilar systems. The agouti's carotid system accounts for vascularization of almost the entire forebrain, while the vertebrobasilar system accounts for vascularization of almost the entire posterior brain (medulla oblongata, pyramid, trapezoid body, cerebellum, bridge, and part of the third caudal section of the forebrain) through the caudal cerebral arteries originating from the terminal branches of the basilar artery. The main arteries on the brain surface include the basilar artery, which is unique, and the arterial pairs, specifically the vertebral arteries, cerebellar caudal arteries, trigeminal artery, rostral cerebellar artery, basilar terminal branch artery, cerebral caudal artery, communicating caudal branch of the cerebral carotid artery, cerebral carotid artery, communicating branch rostral cerebral carotid artery, choroidal rostral artery, medial branch of the communicating branch rostral artery, internal ophthalmic artery, middle cerebral artery, and rostral cerebral artery.
\end{abstract}

Key words: Artery. Brain circuit. Rodent. Dasyproctidae. Agouti.

\section{Resumo}

A cutia é um roedor, que se distribui geograficamente por quase toda América Latina, sendo apreciada pelo sabor da sua carne. Neste trabalho objetivou-se descrever a vascularização arterial da base do encéfalo de cutias, caracterizando o comportamento, origem e distribuição das artérias componentes. Foram utilizados 10 animais do Centro de Multiplicação de Animais Silvestres (CEMAS/UFERSA), pesquisa aprovada pela Comissão de Ética no Uso de Animais (CEUA/ UFERSA- nº 02/2010) e pelo

\footnotetext{
${ }^{1}$ M.e em Ciência Animal, Universidade Federal Rural do Semi-Árido, UFERSA, Mossoró, RN, Brasil. E-mail: saviobessa@ hotmail.com

${ }^{2}$ Discentes de Doutorado em Ciência Animal, UFERSA, Mossoró, RN, Brasil. E-mail: gleidson_benevides@hotmail.com; mvcarlosmagno@gmail.com; ferdinando_vinicios@hotmail.com; fvcamara2@gmail.com

${ }^{3}$ Discente de Mestrado em Ciência Animal, UFERSA, Mossoró, RN, Brasil. E-mail: radan_elvis@hotmail.com

${ }^{4}$ Prof. Pesquisador, UFERSA, Mossoró, RN, Brasil. E-mail: moacir@ufersa.edu.br

* Author for correspondence
} 
SISBIO (N³2413-1). Após eutanásia, os animais foram incisados na cavidade torácica para injeção de Neoprene látex 650 corado na cor vermelha e posterior abertura da calota craniana. Os encéfalos foram extraídos do crânio para análise da sua face ventral e logo fixados em solução aquosa de formaldeído a $10 \%$. A vascularização arterial do encéfalo da cutia apresenta dois componentes principais, o sistema carótico e o vértebro-basilar. O sistema carótico na cutia é responsável pela vascularização do cérebro anterior em quase sua totalidade. O sistema vértebro-basilar é responsável pela vascularização do cérebro posterior (medula oblonga, pirâmide, corpo trapezóide, o cerebelo e ponte e parte do terço caudal do cérebro anterior), através das artérias cerebrais caudais, originárias dos ramos terminais da artéria basilar. As principais artérias presentes na superfície do encéfalo incluem a basilar que é ímpar, e as pares: artérias vertebrais, cerebelar caudal, trigemial, cerebelar rostral, ramo terminal da basilar, cerebral caudal, ramo comunicante caudal da carótida cerebral, carótida cerebral, ramo comunicante rostral da carótida cerebral, corióidearostral, ramo medial do ramo comunicante rostral, oftálmica interna, cerebral média e artéria cerebral rostral.

Palavras-chave: Artéria. Cérebro. Círculo arterial. Roedor. Dasyproctidae. Cutia.

\section{Introduction}

The arteries of the brain lay upon its surface, and the small arteries and arterioles penetrate the brain mass where they branch. It is highly difficult for these branches to anastomose, a feature that favors the occurrence of heart attacks by coagulation or embolism in obliteration cases. The internal carotid artery and the branches of the maxillary artery are the main vessels that supply the brain's blood flow in domestic animals. These branches form the rostral and caudal epidural rete mirabile at the brain's base and penetrate the dura mater close to the middle cerebral or internal carotid artery (in dogs and horses) and form the cerebral arterial circle or arterial circle artery around the infundibulum (KÖNIG; LIEBICH, 2011).

According to Ashwini et al. (2008), the arterial circle is a possible pathway for the collateral circulation at the base of the brain and a subsidiary network of vascular canals that stabilize the cerebral blood flow upon main conducting vessel failure. According to the above authors, there is high variability in the anatomy of the arterial circle, in which asymmetry is the most recurring aspect, whereas the best configuration may be detected in a few cases.

Research on the brain's vascularization started with Tandler (1898) and De Vriese (1905). Henceforth, several studies on brain vascularization have been performed in different species, including dogs (ALCÂNTARA; PRADA, 1996), opossums (LINDEMANN et al., 2000), horses (CAMPOS et al., 2003), cats (LIMA et al., 2006), wild boars (OLIVEIRA, 2004), hedgehogs (AYDIN et al., 2005), and capuchin monkeys (FERREIRA; PRADA, 2005). Brain vascularization was performed in chinchillas (ARAÚJO, 2004) and capybaras (RECKZIEGEL et al., 2001). Since no study of these issues in the agouti has been published to date, the current study was performed. The agouti is a rodent of the suborder Histrycomorpha that belongs to the Dasyproctidae family; is of medium size; and has an adult weight of $1-3 \mathrm{~kg}$. The animal is endemic to Central to South America and has high biological value due to its seed dissemination. Its meat is also highly valued as a native cuisine.

Despite studies on arterial vascularization at the base of the brain, several doubts should be clarified, among which the occurrence of unexpected arterial dispositions in different mammal groups and conceptual issues has suggested the need for further studies in other species (LIMA et al., 2006). It should be emphasized that the encephalic irrigation is a highly relevant issue since its analysis is closely associated with central nervous system development (LINDEMANN et al., 2000). The current paper describes and systemizes the agouti's arteries at the base of the brain while establishing a standard for encephalic vascularization and its main variations in agouti. 


\section{Materials and Methods}

Ten male and female adult agoutis were retrieved from the Center for the Multiplication of Wild Animals (CEMAS) of the Universidade Federal Rural do Semi-Árido (UFERSA), authorized by IBAMA for scientific breeding (Register no. 1478912). The current study was approved by the university's ethics committee (CEUA/UFERSAno. 02/2010) and SISBIO (no. 32413-1).

The animals were first medicated with an association of xylazine hydrochloride $(1 \mathrm{mg} \mathrm{kg}-$ $\left.{ }^{1}\right)$ and ketamine hydrochloride $\left(15 \mathrm{mg} \mathrm{kg}^{-1}\right)$ by intramuscular injection; 10 minutes later, they were euthanized by an intravenous overdose of thiopental $\left(150 \mathrm{mg} \mathrm{kg}^{-1}\right)$ followed by a venous injection of potassium chloride $\left(2.5 \mathrm{mEq} \mathrm{kg}^{-1}\right)$.

Further, the animals' thoracic cavities were incised and opened to gain access to the thoracic aorta, which was cannulated at the cranial section to inject a solution of Neoprene latex (Du Pont do Brasil S.A.) stained with a red pigment (Globo S.A. Tintas e Pigmentos) that was directed the latex toward the brain.

The skin was then removed and an aperture in the cranial dome was performed. The pieces were fixed in a $10 \%$ formaldehyde solution for at least 72 hours, after which the brain, together with a segment of the spine cervical medulla, were removed for dissection and analysis of the arteries at its base. Dissections were done by surgical instruments and a $4 \times$ magnifying glass. At the same time, photos were taken to give support and illustrate the results. Nomenclature from the International Committee on Veterinary Gross Anatomical Nomenclature (2005) was used in the current paper to denominate structures. The results were compared with those of studies on rodents and other mammals in the literature.

\section{Results}

Arterial blood vessels were analyzed macroscopically for their conformation, caliber, and direction and then identified according to common nomenclature. Observations were performed in a rostrocaudal direction from the segment of the spinal cord toward the brain's rostral extremity. A well-developed olfactory tract, similar to that in other rodents, was detected. The current analysis visualized the right and left vertebral arteries, ventral spinal artery, basilar artery with several collateral branches for the two antimeres, right and left terminal branches of the basilar artery, and the carotid cerebral artery with branches extending toward the right and left antimeres.

\section{Vertebral artery}

The vertebral artery has great caliber compared to the other vessels. It projects itself laterally and medially from the lateral vertebral foramen and follows the medulla's ventral surface at an inclination of approximately $45^{\circ}$ until it reaches the medulla oblongata. Every artery in the region emits branches that follow caudally to form the ventral spinal artery. The right and left vertebral arteries consequently anastomose to produce the basilar artery.

\section{Ventral spinal artery}

The ventral spinal artery projects itself in the rostrocaudal direction through the medulla's ventral median fissure and is normally derived from the vertebral arteries close to the formation of the basilar artery, mainly the left vertebral artery. Further, the ventral spinal artery arises exclusively from a single branch that is emitted in a caudal direction by the left vertebral artery (70\%) or is derived from the anastomosis of the small vessels emitted by the two vertebral arteries.

\section{Basilar artery}

The basilar artery rectilinearly follows a rostrocaudal direction through the ventral median line of the rhombencephalon to the bridge's rostral 
extremity, where it divides into two terminal branches, diverging in a laterorostral direction at approximately $90^{\circ}$. The basilar artery accounts for the blood irrigation of the medulla oblongata, trapezoid body, bridge, and cerebellum, producing collateral branches for the two antimeres (Figure 1). The main branches of the basilar artery are the caudal cerebellar arteries, trigeminal arteries, bulbopontine branches, rostral cerebellar arteries, and terminal branches. The behavior of the basilar artery was similar in all of the studied animals.

Figure 1. Photograph of the ventral surface of the brain of Dasyprocta aguti with the cerebellar vessels and bulbopontine branches visible: (1) ventral spinal artery; (2) right and left vertebral arteries; (3) basilar artery; (4) right and left rostral cerebellar arteries. Bar $=1 \mathrm{~cm}$.

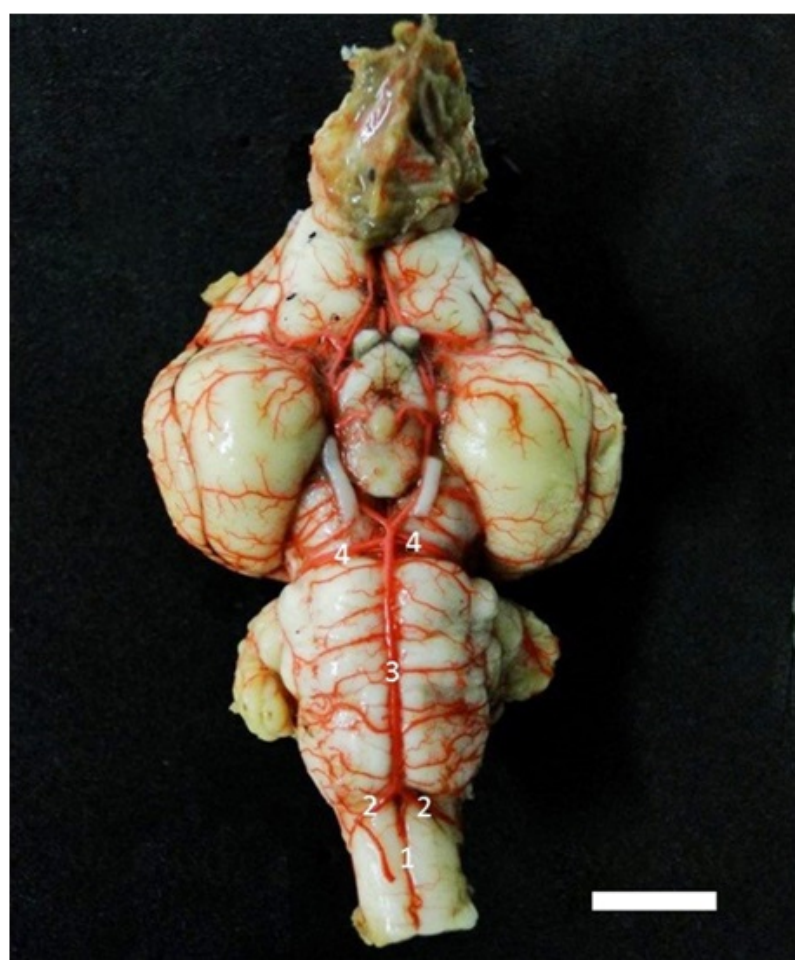

The basilar artery's most calibered branch in nine of the animals $(90 \%)$ was the caudal cerebellar artery derived from the middle region of the medulla oblongata arising from the basilar artery. The left caudal cerebellar artery in one animal $(10 \%)$ was derived from its contralateral homolog (Figure 2).
Figure 2. Photograph of the ventral surface of the brain of Dasyprocta aguti with the cerebellar vessels and bulbopontine branches visible: (1) basilar artery; (2) right and left caudal cerebellar arteries; (3) right and left trigeminal arteries; (4) right and left rostral cerebellar arteries. $\mathrm{Bar}=1 \mathrm{~cm}$.

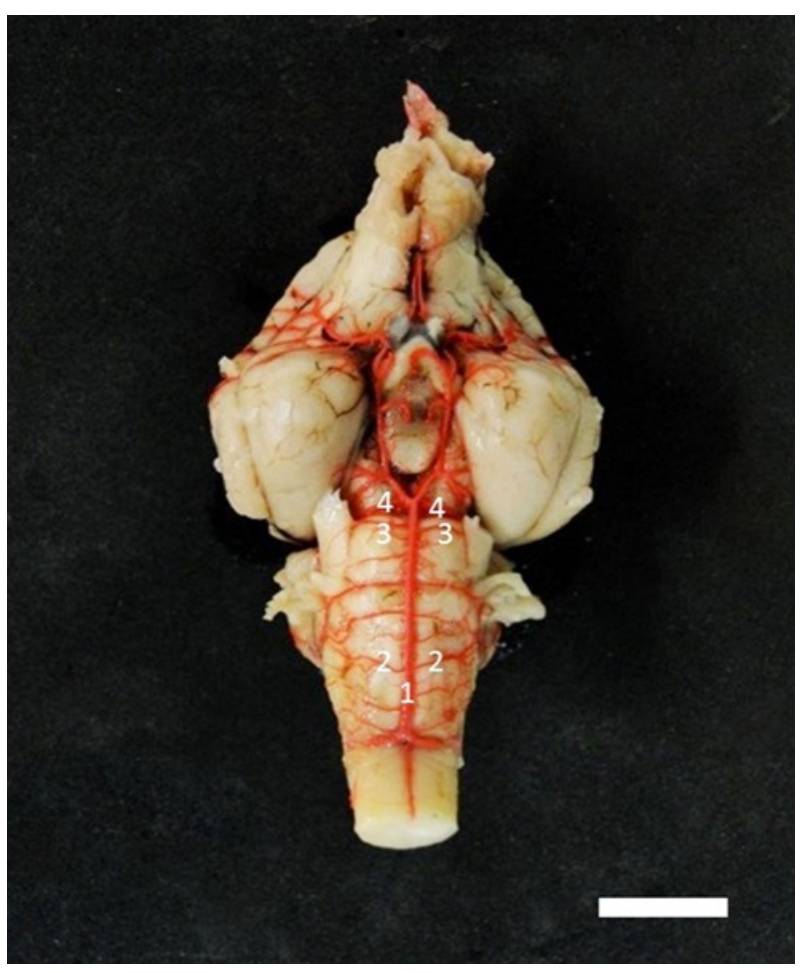

Trigeminal artery

The trigeminal artery originated from the bridge's rostral extremity, ran through the ventral surface of the structure, and projected itself laterally, reaching the apparent base of the trigeminal nerve in all of the studied animals.

\section{Rostral cerebellar artery}

The right and left cerebellar arteries are derived from two different caliber branches close to the bridge's rostral farrow at the start of the interpeduncular fossa. In a laterocaudal direction, they bypass the cerebral peduncle until they reach the rostral portion of the cerebellum. Here, in $40 \%$ of cases, the branches of the rostral cerebellar artery were derived entirely from the basilar artery (Figure $2)$. In the case of five brains $(50 \%)$, the thinnest 
branch was derived from the basilar artery, while its pair originated from the terminal branch of the basilar artery (50\%). The two branches were derived from the terminal branch of the basilar artery in one animal $(10 \%)$.

\section{Terminal branches of the basilar artery}

The basilar artery's terminal branches originated from the bifurcation of the basilar artery and diverged at approximately $90^{\circ}$, where they provided the rostral cerebellar artery and diagonally small but numerous branches to the mammillary body until the caudal cerebellar artery toward the rostrum. Near the hypophysis, the two terminal branches produced the same caliber branch that penetrated the dura mater toward the rostrum as communicating caudal branches of the internal carotid artery. The terminal branch of the basilar artery in 50\% of the vascular molds contributed toward the origin of the rostral cerebellar artery and accounted for the formation of the rostral cerebellar artery in $10 \%$ of cases.

\section{Cerebral caudal artery}

The agouti's cerebral caudal artery is directed laterodorsally and reaches the transverse fissure and the most caudal section of the brain with a variegated number of branches originating from the terminal branches of the right and left four-branch basilar artery. The right caudal cerebral artery in four animals $(40 \%)$ is composed of two branches originating from the right terminal branch of the basilar artery. However, in two animals (20\%), the right caudal cerebral artery is composed of four branches; in another two (20\%), it originates from the right terminal branch of the basilar artery, while one $(10 \%)$ is either unique or composed of three branches. The artery in its left branch with five molds was composed of two branches that originated from the terminal branch of the left basilar artery; in three animals, it was composed of three branches originating from the right terminal branch. The basilar artery's right terminal branch in one animal arose from a common trunk that was either unique or provided two branches originating from the right terminal branch of the basilar artery (Figure 3).

Figure 3. Photograph of the ventral surface of the brain of Dasyprocta aguti with vessels that irrigate the brain visible: (1) terminal branches of the right and left basilar artery; (2) caudal communicating branches of the right and left carotid arteries; (3) right cerebral carotid artery; (4) right and left middle cerebral arteries; (5) right and left rostral cerebral arteries; (a) rostral communicating branches of the right and left cerebral carotid arteries. Bar $=1 \mathrm{~cm}$.

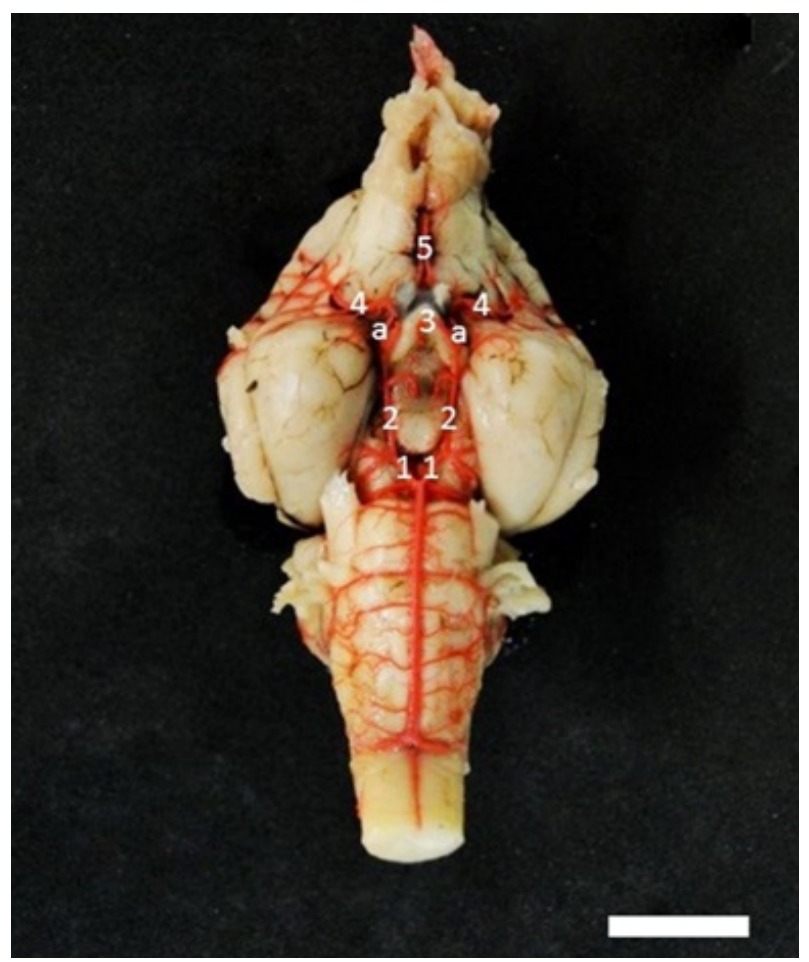

\section{Cerebral carotid arteries}

The agouti's cerebral carotid arteries undergo a tortuous trajectory through the cavernous sinus until they reach the dura mater, penetrate it, and traverse the sinus close to the optic chiasm. Upon reaching the brain's ventral surface, the cerebral carotid artery divides into the caudal and rostral communicating branches. The former anastomoses with the terminal branch of the basilar artery when it receives the 
great caliber vessel from the carotid system and, as with the communicating branch, penetrates the dura mater. In its trajectory, the caudal communicating branch is directed laterally to the normally single rostral choroidal artery excepting in animals with two branches. It is then directed laterally and inserts itself into the fissure between the cerebral peduncle and the piriform lobe.

The other communicating branch binds to the rostrum, bypasses the optic chiasm, and frequently emits small-caliber vessels to the ventral surface of the piriform lobe. Small medial branches emerged from the right and left branches, dorsally followed the optic nerve, and anastomosed by closing the arterial circuit while giving rise to the interhemispheric artery in eight animals (80\%). In the meantime, the left medial branch in one animal (10\%) was derived from the left rostral cerebral artery and, in one case $(10 \%)$, the right rostral communicating branch of the cerebral carotid failed to emit the medial branch. The arterial circle remained open and the interhemispheric artery was formed exclusively by the left medial branch.

The rostral communicating branch of the cerebral carotid reveals a bifurcation that gives rise to the medial and rostral cerebral arteries. In most cases $(90 \%)$, the medial cerebral artery is a single vessel, binds laterally, and emits the vessel inclusively to the piriform lobe and the brain's mediolateral area. It reaches the dorsal surface and distributes itself tree-wise. The artery in one animal (10\%) was not a single vessel but a double vessel near the optic tract. The rostrocerebral artery binds in a mediorostral manner by the ventral surface of the olfactory trigone, follows the brain's longitudinal fissure and reaches the olfactory bulbs at the forebrain extremity. One animal, however, lacked a left rostral cerebral artery. In that case, the interhemispheric artery produced small-caliber branches to supplement the region's vascularization.

The communicating rostral and caudal branches normally run in the rostral and caudal directions to the two sides of the hypophysis to unite to the corresponding ones on the opposite side and thus form the cerebral artery circle (Figure 4).

Figure 4. Photograph of the vertebrobasilar and carotid system of the brain of Dasyprocta aguti showing the: (a) ventral spinal artery; (b) right and left vertebral arteries; (c) basilar artery; (d) right and left caudal cerebellar arteries; (e) right and left trigeminal arteries; (f) right and left rostral cerebellar arteries; $(\mathrm{g})$ terminal branches of the right and left basilar arteries; (h) right and left caudal cerebral arteries; (j) right and left cerebral carotid arteries; (l') rostral communicating branch of the left cerebral carotid; (m) right and left medial cerebral arteries; (n) right and left rostral cerebral arteries. Bar $=1 \mathrm{~cm}$.

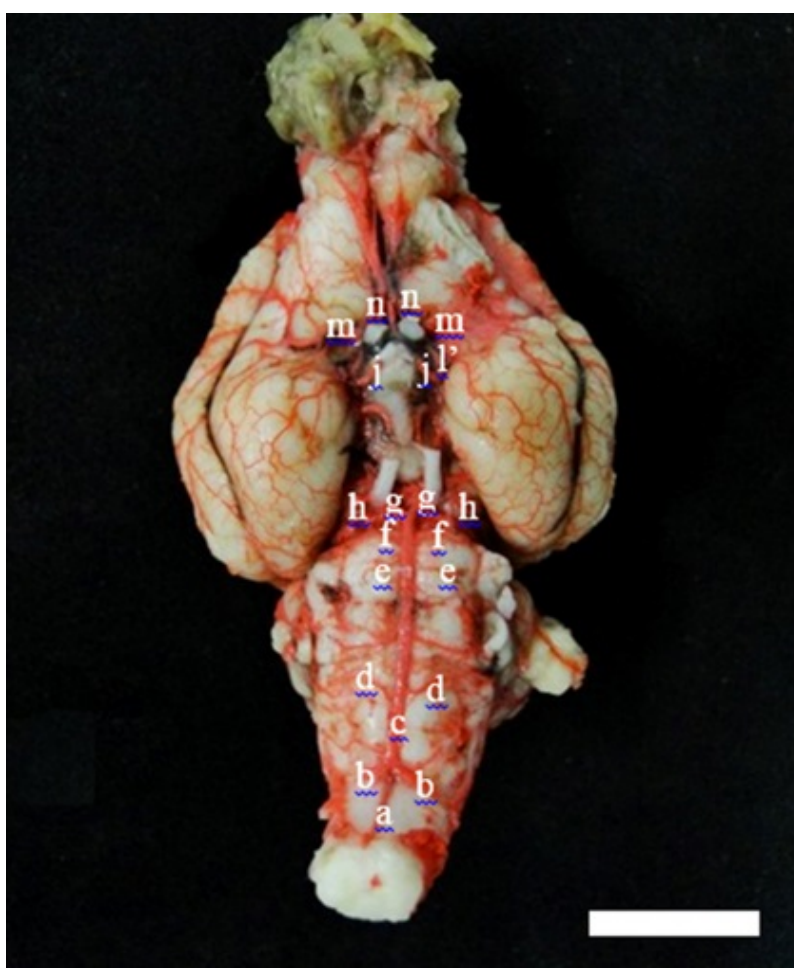

\section{Discussion}

According to classification by De Vriese (1905), the agouti's brain has a type II arterial vascularization, with two main components for the formation of the arterial circuit, namely the carotid and vertebrobasilar systems. The above is similar to results in dogs (ALCÂNTARA; PRADA, 1996), cats (LIMA et al., 2006, 2010), horses (SOUZA et al., 2010), opossums (LINDEMANN et al., 2000), 
capuchin monkeys (FERREIRA; PRADA, 2005), rodents (Spalax leucodon) (AYDIN et al., 2008), coatis (BARREIRO et al., 2012), rabbits (SOUZA; CAMPOS, 2013), pigs (MATOS et al., 2013), and anteaters (LIMA et al., 2013). On the other hand, Reckziegel et al. (2001) and Araújo (2004) studied the arteries at the base of the brain of capybaras and chinchillas, respectively, and reported that the brain vascularization of these species depends solely or almost exclusively on the vertebrobasilar system and differs from results provided by experiments on the agouti. Aydin et al. (2005) analyzed the brain's arterial circuit of the hedgehog (Hystrix cristata) and registered that the internal carotid artery does not belong to the cerebral arterial circle since the circle is merely derived from the basilar artery. This fact contrasts the current results in which the carotid artery divides itself into the caudal and rostral communicating branches, and the latter is highly relevant to closure of the arterial circle.

The agouti's right and left vertebral arteries join to form a greater caliber vessel, and the basilar artery has an anatomical disposition similar to that described by Azambuja et al. (2006) about on the systematization of the arteries at the base of the brain of the nutria or coypu. However, Tandler (1898), in comparative studies on mammals, reported that the vertebral arteries of the African jumping hare did not participate in brain vascularization or, rather, reported findings that differed from the current results. The ventral spinal artery of the agouti is derived from the left vertebral artery as reported by Araújo (2004) on chinchillas. On the other hand, Souza and Campos (2013) studied the systematization of the arteries at the base of the brain in rabbits and reported that the vessel is frequently derived from the anastomosis of the right and left vertebral arteries and may originate solely from the left or right vertebral artery. Further, Lima et al. (2006) studied the arterial vascularization of cats' brains and discovered that, in the transition from the medulla oblongata to the spinal medulla, the right and left vertebral arteries produced branches in the rostrocaudal direction that anastomosed and formed the ventral spinal artery. It must be emphasized that results on the origin of the ventral spinal artery of the agouti differed from those reported by Souza and Campos (2013) and by Lima et al. (2006). In fact, the vessels in the agouti are derived solely from branches of the left vertebral artery. Campos et al. (2003) described the arteries at the base of the horse brain and reported that the ventral spinal artery originated from anastomosis of the branches coming from the right and left occipital arteries and, thus, differed absolutely from the pattern in the agouti.

The agouti's basilar artery was derived from the anastomosis of the right and left vertebral arteries and followed a rectilinear trajectory similar to that described for the chinchilla (ARAÚJO, 2004), hedgehog (AYDIN et al., 2005), dog (PAIS et al., 2009), cat (SALVADOR-GOMES et al., 2012), coati (BARREIRO et al., 2012), rabbit (SOUZA; CAMPOS, 2013), and anteater (LIMA et al., 2013). Alcântara and Prada (1996) and Lima et al. (2006) reported that the basilar artery in the dog and cat, respectively, had a rather winding form that differed from that in the agouti. Studies on fetuses of zebu cattle by Melo and Prada (1998) verified that the basilar artery was a unique vessel derived from the right and left caudal branches of the carotid arteries, unlike that in the agouti. Further, Ashwini et al. (2008) reported that the vessel in ruminants may be considered a branch originating from the arterial circle and not from the vertebral arteries along with a decrease in the rostrocaudal caliber.

The agouti's right and left cerebellar arteries were anatomically similar to those described by Câmara Filho et al. (2004) and Matos et al. (2013) in studies on the pig and coati (BARREIRO et al., 2012). The agouti's caudal cerebellar artery was derived ventrally from the medulla oblongata, followed a lateral path, and produced branches to irrigate the cerebellum's caudal section, which was also corroborated by Lima et al. (2013) for the anteater. These authors reported that the caudal 
cerebellar artery projected itself laterally to irrigate the caudal and laterocaudal sections of the cerebellar hemispheres. Reckziegel et al. (2001) and Araújo (2004) described the capybara and the chinchilla, respectively, and reported that the artery, after originating from the basilar artery, projected itself laterally toward the interior of the transverse fissure and distributed itself in the mesencephalon and the caudal end of the cerebral hemispheres. Further, Lazorthes et al. (1976) reported that the caudal cerebellar artery in mice (Mus musculus) irrigated the brain's caudal region in contrast to that reported in the agouti, whose vessel provided the irrigation of the cerebellum's caudal portion.

The behavior of the agouti's trigeminal arteries is similar to that described for the coati by Azambuja (2006), who reported that these branches exited at the bridge some millimeters from the terminal branches of the basilar artery. Similarly, Souza, and Campos (2013) registered that the trigeminal arteries in the rabbit were small-caliber vessels that arose from the basilar artery and directed themselves toward the trigeminal nerve and its ganglia in the two antimeres. However, the current results differed from those by Souza and Campos (2013) in the case of the rabbit. In fact, these authors stated that the artery may arise as a branch of the rostral cerebellar artery. However, this fact was not detected in the agouti. On the other hand, Lima et al. (2006) failed to describe the trigeminal arteries in studies on the cat.

Lazorthes, Gouazé, and Salamon (1976) reported that rodents' rostral cerebellar arteries originated from posterior carotid-basilar communication or caudal communication artery. The agouti's right and left rostral cerebellar arteries were derived from the terminal branches of the basilar artery. In his description of the rat nervous system, Scremin (1995) observed that these arteries appeared, as a rule, in pairs called the upper cerebellar arteries that came directly from the basilar artery. The behavior of the rostral cerebellar arteries corresponded to that in the agouti. According to Reckziegel et al.
(2001), the rostral cerebellar arteries in the capybara originated from the terminal branches of the basilar artery, directed themselves laterally following the rostral pontine farrow, and distributed themselves on the lateral and rostral surfaces of the lateral cerebellar hemispheres and on the rostral and dorsal surfaces of the cerebellar vermis. Souza and Campos (2013), on the other hand, reported that the rabbits' rostral cerebellar arteries accounted for the irrigation of almost the entire cerebellum.

According to Tandler (1898) and De Vriese (1905), the basilar artery in animals, from which cerebral vascularization exclusively originated by the vertebral arteries, went beyond the bridge region and divided itself into two branches of the same caliber. The branches directed themselves toward the rostrum along the brain's base. Each gave origin to the brain's deep artery, the caudal cerebral artery, as was reported in the agouti.

From studies on mammals, De Vriese (1905) reported that the caudal cerebral artery was embryologically a collateral branch of the caudal terminal branch of the internal carotid artery. In some animals, through an increase in the participation of the vertebrobasilar complex, it became the collateral branch of the basilar artery's terminal branches. Studies on the chinchilla by Araújo (2004) reported that the caudal cerebral artery corresponded to a single or double vessel despite this artery in the agouti being a single vessel with four terminal branches. Reckziegel et al. (2001) reported that the caudal cerebral artery of the capybara arose from the terminal branches of the basilar artery and projected itself laterally, normally double on the right and single on the left sides. This is very similar to reports on the agouti. In rabbits (SOUZA; CAMPOS, 2013) and cats (LIMA et al., 2010), the caudal cerebral artery originated from the anastomosis between the internal carotid artery and the terminal branch of the basilar artery, which was lacking in the agouti.

When the agouti's cerebral carotid artery reaches the brain's ventral surface, it divides itself into 
the caudal and rostral communicating branches. Ashwini et al. (2008) emphasized that the cerebral carotid artery in ruminants and pigs behaved similarly to that of the agouti throughout its pathway, whereas the vessel in humans was merely a connecting point between the rostral cerebral and medium cerebral arteries. Câmara Filho et al. (2004) observed that the cerebral carotid arteries in pigs provided the caudal communicating branches, followed ventrorostrally toward the optic tract, directed themselves to the dorsal median plane, and continued rostrally as rostral cerebral arteries. However, in the case of the coypu's medial branches of the rostral communicating branch of the right and left cerebral carotid arteries, Azambuja (2006) reported that the medial branch closed the arterial sinus circle when it anastomosed with its homolog. Further, part of the rostral cerebral artery differed from results on the agouti since that species' medial branch originated from the rostral communicating branch of the cerebral carotid artery.

Lazorthes et al. (1976) described the posterior communicating arteries of mice (Mus musculus) and showed the residues of the caudal branches of the internal carotid arteries. The same authors stated that the posterior communicating artery in rats (Rattus norvegicus) is derived directly from the internal carotid artery and joins the bifurcation branch of the basilar trunk. The above finding was similar to that described in the agouti in which the vessel originated from the carotid system and, similar to the communicating branch, penetrated the dura mater, although it was not possible to pinpoint its precise origin. The agouti's rostral choroid artery normally arises as a single branch from the caudal communicating branch. In the case of the coypu, Azambuja (2006) reported that the vessel was unique, as verified in the agouti, or a double vessel. On the other hand, the hedgehog's rostral choroid artery (AYDIN et al., 2005) originated from the rostral cerebral artery and divided itself into two branches, extending itself on the piriform lobe so that it might irrigate the lateral ventricle and the hippocampus. Data on the origin of the agouti's rostral choroid artery differed from those by Souza and Campos (2013) on the rabbit, whose collateral branch was the internal carotid artery and from the results by Alcântara and Prada (1996), which stated that the dog's rostral choroid artery was a branch of the middle cerebral artery.

The agouti's middle cerebral artery is derived from the rostral communicating branch of the cerebral carotid, near the optic tract, and followed a lateral direction to provide vessels inclusively to the piriform lobe and the brain's lateral middle section. Alcântara and Prada (1996) reported that, in dogs, the vessel originated from the rostral branch of the internal carotid and provided not only the rostral choroid arteries but also the branches for the piriform lobe. Lindemann et al. (2000) stated that the vessel in the opossum was derived from the midrostral cerebral trunk, directed itself laterally through the interior of the lateral furrow, rostrally bypassed the piriform lobe, and finally projected itself dorsally. According to the same authors, prior to being derived from the brain's base, the middle cerebral artery produced rostral and caudal ventral branches that distributed themselves to the olfactory trigone, olfactory peduncle, lateral olfactory tract, and piriform lobe. Lima et al. (2013) reported that the anteater's middle cerebral artery arose from the internal carotid artery in contrast to that in the agouti. The pig's middle cerebral artery had one to three segments that were derived from the rostral branch of the internal carotid artery and then passed dorso- and rostrolaterally to the piriform lobe and the ventral surface of the perforated rostral substance until it reached the lateral rhinal furrow. It then distributed itself dorso- and rostrolaterally in the cerebral hemisphere as described by Câmara Filho et al. (2004). The cerebral artery in the agouti was double.

Similar to the middle cerebral artery, the agouti's rostral cerebral artery originated from the bifurcation of the rostral communicating branch of the cerebral carotid artery. Jablonski and Brudnicki 
(1984) reported that the chinchilla's rostral cerebral artery started from the internal carotid artery and directed itself rostrally. Azambuja (2006) stated that the coypu's rostral cerebral artery was one of the terminal branches of the basilar artery rising from the emission of the middle cerebral artery (RECKEZIEGEL et al., 2001; ARAÚJO, 2004). De Vriese (1905) stated that data related to ontogenesis and phylogenesis indicated that the rostral cerebral artery was the only terminal branch of the internal carotid artery, data that differed from those of the agouti.

In a systematic analysis of the arteries at the base of the capybara's brain, Reckziegel et al. (2001) observed the lack of the rostral cerebral artery in $6.7 \%$ of cases on the right and in $3.3 \%$ of cases on the left. Araújo (2004) reported that the rostral cerebral artery was lacking in 3.3\% of cases in the chinchilla on the right and left. The author also remarked that a thin vestigial vessel might be found where the rostral cerebral artery originated. Accordingly, the rostral cerebral artery developed on the opposite antimere emitted collateral branches that compensated for the deficiency. It should be emphasized that in the infrequent case $(10 \%)$ of lack of a left rostral cerebral artery in the agouti, the interhemispheric artery provided small-caliber branches to compensate for the vascularization of the region.

Therefore, the arterial vascularization of the agouti's brain contributes to the vertebrobasilar complex and the carotid system in a relatively equivalent manner. The agouti's carotid system accounted for the vascularization of almost the entire rostral brain. On the other hand, the vertebrobasilar system accounted for the vascularization of the caudal region of the brain, the third caudal section of the forebrain, and part of the third caudal section of the brain. The agouti showed a pair of highly developed vertebral arteries that contributed to the brain's blood supply, as in most of the animals analyzed here.
This species' arterial circle was normally complete and closed, bypassing the mammillary body, cinereal tuber, and optic chiasm. It had a hexagonal shape and was long in the rostrocaudal direction. Six vertexes were determined by the points in which bifurcation occurred of the basilar artery, emission of the right and left caudal cerebral arteries, bifurcations that provided the middle and rostral cerebral arteries, and finally, anastomosis of the medial branches of the rostral communicating branch.

\section{Conclusion}

The agouti's arterial circle is normally complete and closed, bypassing the mammillary body, the cinereal tuber, and optic chiasm. It is supplied by two great sources, namely the vertebrobasilar and carotid systems. This species' type II brain irrigation differed from that of rodents such as the capybara and the chinchilla; rather, it was closer to that of domestic carnivores including the horse, pig, lagomorph, and capuchin monkey.

\section{References}

ALCÂNTARA, M. A.; PRADA, I. L. S. Artérias da base do encéfalo de cães (Canis familiaris, LINNAEUS, 1758). I. Estudo anatômico de suas origens e comportamento. Brazilian Journal of Veterinary Research and Animal Science, São Paulo, v. 33, n. 2, p. 67-71, 1996.

ARAÚJO, A. C. P. Sistematização das artérias da base do cérebro e suas fontes de suprimento sanguíneo em chinchila (Chinchilla lanigera). 2004. Dissertação (Mestrado em Ciências Veterinárias) - Programa de Pós-Graduação da Faculdade de Medicina Veterinária, Universidade Federal do Rio Grande do Sul, Porto Alegre.

ASHWINI, C. A.; SHUBHA, R.; JAYANTHI, K. S. Comparative anatomy of the circle of Willis in man, cow, sheep, goat, and pig. Neuroanatomy, Ankara, v. 7, p. 54$65,2008$.

AYDIN, A.; YILMAZ, S.; DINC, G.; OZDEMIR, D.; KARAN, M. The morphology of circulus arteriosus cerebri in the porcupine (Hystrix cristata). Veterinary Medicine Czech, Prague, v. 50, n. 3, p. 131-135, 2005. 
AYDIN, A.; YILMAZ, S.; OZKAN, Z. E.; ILGÜN, R. Morphological investigations on the Circulus Arteriosus Cerebri in mole-rats (Spalax leucodon). Anatomia, Histologia, Embryologia, Berlin, v. 37, n. 3, p. 219-222, 2008.

AZAMBUJA, R. C. Sistematização das artérias da base do encéfalo e suas fontes de suprimento sanguíneo em nutria (Myocastor Coypus). 2006. Dissertação (Mestrado em Anatomia) - Curso de Pós-Graduação em Ciências Veterinárias, Universidade Federal do Rio Grande do Sul, Porto Alegre.

BARREIRO, J. R.; CARVALHO, A. F.; FRANCIOLLI, A. L. R.; FERREIRA, G. J. B. C.; FERREIRA, J. R.; AMBRÓSIO, C. E.; MIGLINO, M. A. Morfologia dos vasos da base do encéfalo do quati (Nasua nasua). Pesquisa Veterinária Brasileira, Seropédica, v. 32, n. 6, p. 567-572, 2012.

CÂMARA FILHO, J. A.; SILVA, B. R. S. A.; SILVEIRA, R. L.; SCHERER, P. O. Características morfológicas da distribuição vascular cerebral de Sus scrofa Linnaeus 1758 (Mammalia, Artiodactyla). Revista Brasileira de Zoologia, Curitiba, v. 21, n. 4, p. 955-959, 2004.

CAMPOS, A.; PRADA, I. L. S.; SANTOS JÚNIOR, I.; SANTOS, D. Artérias da base do encéfalo de equinos: sistema occipito-basilar. Brazilian Journal of Veterinary Research and Animal Science, São Paulo, v. 40, p. 107117, 2003. Suplemento 2.

DE VRIESE, B. Sur la signification morphologique des artères cérébrales. Archives de Biologie, Liège, v. 21, n. 1904, p. 357-457, 1905.

FERREIRA, C. G.; PRADA, I. L. S. O circuito arterial da base do encéfalo em suínos (Sus scrofa domesticus Linnaeus, 1758), formação e comportamento. Brazilian Journal of Veterinary Research and Animal Science, São Paulo, v. 42, n. 1, p. 53-60, 2005.

INTERNATIONAL COMMITTEE ON VETERINARY GROSS ANATOMICAL NOMENCLATURE. Nomina Anatomica Veterinária. $5^{\text {th }}$ ed. Knoxville: World Association on Veterinary Anatomist, 2005. 177 p.

JABLONSKI, R.; BRUDNICKI, W. The effect of blood distribution to the brain on the structure and variability of the cerebral arterial circle in musk-rat and in chinchilla. Folia Morphologica, Warszawa, v. 43, n. 2, p. 109-114, 1984.

KÖNIG, H. E.; LIEBICH, H. G. Anatomia dos animais domésticos: texto e atlas colorido. Porto Alegre: Artmed, 2011. $788 \mathrm{p}$.

LAZORTHES, G.; GOUAZÉ, A.; SALAMON, G. Anatomie comparée du système artéril de l'encéphale. In: . (Ed.). Vascularization et circulation de l'encéphale. Paris: Masson, 1976. p. 14-30.
LIMA, A. R.; PEREIRA, L. C.; BRANCO, E. Anatomia do circuito arterial do encéfalo em Tamanduá-mirim. Ciência Rural, Santa Maria, v. 43, n. 2, p. 277-282, 2013.

LIMA, E. M. M.; PRADA, I. L. S.; SILVA, F. O. C.; SEVERINO, R. S.; SANTOS, A. L. Q.; BORGES, B. O.; PAIM, T. P.; VIANNA, A. R. C. B. Sistematização da origem, da distribuição e dos territórios da artéria cerebral caudal na superfície do encéfalo em gatos. Ciência Rural, Santa Maria, v. 40, n. 9, p. 1961-1965, 2010.

LIMA, E. M. M.; PRADA, I. L. S.; SILVA, F. O. C.; SEVERINO, R. S.; SANTOS, A. L. Q.; DRUMMOND, S. S.; RODRIGUES, G. S. Estudo anatômico das artérias da base do encéfalo em gatos. Ars Veterinária, Jaboticabal, v. 22, n. 1, p. 1-7, 2006.

LINDEMANN, T.; RECKZIEGEL, S.; CAMPOS, R. A systematic study of brain Base arteries in the Opossum Didelphis albiventris. Brazilian Journal of Morphological Science, São Paulo, v. 17, n. 1, p. 35-41, 2000.

MATOS, S. A.; PASSOS, N. C.; HERNANDEZ, J. M. F.; PALHANO, H. B.; ANTUNES, M. S.; SCHERER, P. O. Estudo morfológico da vascularização arterial da base do encéfalo de suínos (Sus scrofa domesticus, Linnaeus, 1758) mestiços. Revista Brasileira de Medicina Veterinária, Rio de Janeiro, v. 35, n. 4, p. 365-370, 2013.

MELO, A. P. F.; PRADA, I. L. S. Anatomical study of arteries of the base of encephalon in fetuses of zebu crossed bovines. Brazilian Journal of Morphological Science, São Paulo, v. 15, n. 2, p. 143-149, 1998.

OLIVEIRA, J. C. D. Sistematização das artérias da base do encéfalo, rede admirável epiduralrostral e caudal e suas fontes de suprimento em javali (Sus scrofascrofa). 2004. Tese (Doutorado em Anatomia) - Curso de PósGraduação em Ciências Veterinárias, Universidade Federal do Rio Grande do Sul, Porto Alegre.

PAIS, D.; ARANTES, M.; CASAL, D.; CASIMIRO, M.; O'NEILL, J. G. Brain stem arteries in Canis familiarisimplications in experimental procedures. Brazilian Journal of Morphological Science, São Paulo, v. 26, n. 1, p. 8-11, 2009.

RECKZIEGEL, S. H.; LINDEMANN, T.; CAMPOS, R. A systematic study of the brain base arteries in capybara (Hydrochoerus hydrochaeris). Brazilian Journal of Morphological Sciences, São Paulo, v. 18, n. 2, p. 103110, 2001

SALVADOR-GOMES, M.; HERNANDEZ, J. M. F.; ALONSO, L. S.; ABIDU-FIGUEIREDO, M. Morfologia e ramos principais da artéria basilar em gatos. Revista Brasileira de Medicina Veterinária, Rio de Janeiro, v. 34, n. 3, p. 206-212, 2012. 
SCREMIN, O. U. Cerebral vascular system. In: PAXINOS, G. The rat nervous system. $2^{\text {th }}$ ed. San Diego: Academy Press, 1995. cap. I, p. 3-18.

SOUZA, A. V. P.; XAVIER-SILVA, B.; ANTUNES, M. S.; HERNANDEZ, J. M. F.; SCHERER, P. O.; ABIDUFIGUEIREDO, M. Frequência da artéria caroticobasilar em equinos mestiços: estudo anatômico destinado a pesquisa experimental e ao diagnóstico por imagem. Pesquisa Veterinária Brasileira, Seropédica, v. 30, n. 8, p. 685-688, 2010.
SOUZA, F.; CAMPOS, R. A systematic study of the brain base arteries in the rabbit (Oryctolaguscuniculus). Pesquisa Veterinária Brasileira, Seropédica, v. 33, n. 6, p. 796-806, 2013.

TANDLER, J. Zur vergleichenden anatomie der kopfarterienbei den mammalia. Denkschr Akademie Wissenchaften, Berlin, v. 67, n. 2, p. 677-689, 1898. 